\title{
Communities of practice in the conservatory: learning with a professional musician
}

\section{Esa Virkkula}

School of Vocational Teacher Education, Oulu University of Applied Sciences, Oulu, Finland

esavirkkula@gmail.com

This article examines the sociocultural learning of popular and jazz music in communities of practice as part of secondary vocational music education in a Finnish conservatory. The research is based on performance workshops which were implemented as a joint effort between professional musicians and music students. These workshops are suggested as a method of utilising communities of practice. Research outcomes show that the workshops include opportunities for learning and developing musicianship on many levels. The potential of sociocultural learning should be recognised in music schools and teachers should develop learning environments which utilise it. Learning from playing experiences and from the evaluation of learning outcomes are largely the students' responsibility who require autonomy, initiative, the ability to solve problems and collaborate, and a readiness to reflect on experiences.

\section{Introduction}

In Finnish conservatories, efforts have been made since the beginning of the 1990s to strengthen the status of popular and jazz music (Purma, 2012, pp. 23-24). This trend has been of great national importance, since the network of conservatories throughout the country offer studies both to children who have music as a hobby and to young adults who study for vocational qualifications. The studies of popular and jazz music have been integrated into conservatory activities following the training traditions of European classical music with an emphasis on instrumental, ensemble and theoretical studies. Music examinations have been arranged regularly to measure learning (cf. Finnegan, 1989; Walser, 1993; Gatien, 2009).

What is typical of conservatory studies is gaining musical knowledge as an individual process of growth with the teacher still having a significant role (e.g. Green, 2001; Fautley, 2010; Creech, 2012; Robinson, 2012; Gaunt \& Westerlund, 2013; Partti et al., 2013). According to educational tradition, the teacher chooses the material to be played and divides it into suitable portions. The learner practices each portion and aims for the eventual mastery of the whole music piece. The teacher gives feedback, demonstrates how the parts should be played and defines when the student's skill is sufficient.

These teacher-centred practices have recently been challenged (e.g. Green, 2001; Jaffurs, 2004; Folkestad, 2006; Feichas, 2010; Finney \& Philpott, 2010; Wright \& Kanellopoulos, 2010). Discussion has been stimulated e.g. by Lucy Green's studies (2001, 2006, 2008) on learning popular music. Inspired by her work, for instance, Gatien (2009, 
p. 113) has stated that the focus in formal jazz music is 'to learn things that jazz musicians master. Instead, the focus should also be in communal methods through which jazz musicians have learnt their skills'. According to Mans (2009, p. 90), the question concerns the fact that in formal education, there seems to be 'a lack of understanding about the importance of learners' making their own choices in music and in method, and taking responsibility for the outcomes'.

The starting point of this study is the conception that the development of musicianship in popular and jazz music will require a wider pedagogical perspective than is currently the norm (Boud et al., 1999; Ake, 2002; Boud \& Middleton, 2003; Sadler, 2005; Folkestad, 2006; Gaunt \& Westerlund, 2013). Mere teacher-centred 'forwarding' of musical knowledge may lead to the development of external stereotypes in the student, which is not the best possible result concerning knowledge (Leppänen et al., 2013).

This research examines learning in a sociocultural framework which sees the development of competence as a construction of new skills and knowledge through a communal process in communities of practice (Lave \& Wenger, 1991; Wenger, 1998, 2009), often without verbal communication (Rogoff, 2003; Bennett, 2005, p. 263). This viewpoint is relatively new in music education. During the last few years, the role of the community has been evaluated in the learning of singing (Johansson, 2013; Latukefu \& Verenikina, 2013; van Zelm, 2013), playing (Väkevä, 2010; Carrucci, 2012; Ballantyne \& Lebler, 2013; Johansson, 2013; Luff \& Lebler, 2013; Rikandi, 2013; Kenny, 2014) and composing (Salavuo, 2006; Partti \& Karlsen, 2010; Thorpe, 2012; Partti \& Westerlund, 2013).

The first part of this article will deal mainly with the studies by Etienne Wenger $(1998,2009)$ of sociocultural learning in communities of practice. Sociocultural learning is typically seen when individuals participate in the activities of music communities, e.g. in orchestras and ensembles.

The second part will introduce the workshop method of popular and jazz music learning with a Finnish frame of reference and will evaluate its added value in the education of musicians. The latter refers to a new kind of sociocultural pedagogical action which requires the student to take an active role as an actor in a musical community of practice: as a planner of his/her own learning, as an implementer and as the evaluator of the outcomes. The workshop method also requires new skills from the teacher; a wider perspective than previously held in terms of learning and teaching (cf. Cope, 2005; Sadler, 2005; Lebler, 2007; Gatien, 2009). The research will explain the connections between acting in musical communities of practice and a student's learning in a conservatory by asking the following research questions:

(1) How can communities of practice be utilised in a conservatory?

(2) How is a community of practice connected to the development of musicianship?

\section{Sociocultural learning in communities of practice}

Wenger's research on communities of practice $(1998,2009)$ has been considered a bridge-builder theory between the individual and social elements of learning. In his book Communities of Practice, Wenger (1998; later e.g. Wells \& Claxton, 2002, p. 7; Ardichvili, 
2008; Kietzmann et al., 2013, pp. 283-4) suggests that sociocultural learning takes place in small collaborative groups, i.e. communities of practice, which share three components: joint enterprise, mutual engagement and a shared repertoire. The last element refers to the interaction traditions of the community, to the artefacts, the action and the concepts. In sociocultural learning, the development of competence is not only through the individual gaining knowledge under the teacher's direction but also through action in the communities in which the knowledge is created and used.

Wenger's conception of the social character of learning can be seen as a communal interpretation of Vygotsky's studies on the role of social relations in learning. Vygotsky (1978) introduced two levels of learning: (1) the inter-psychological construction of knowledge in social interaction and (2) the intra-psychological process. In both, interaction, action and concepts have significant roles (see also Wells \& Claxton, 2002, p. 4).

Wells (1999, p. 321) adds that Vygotsky's view on learning should not be understood as a mechanical chain of transferring knowledge from the outside inwards, but, instead, as an intercourse of inter- and intra-psychological processes. When people meet each other, their views are revealed and become shaped in interaction as communal and individual processes aided by a sociocultural repertoire. It is essential to be aware of the significance of communal interaction in the construction of an individual's inner interaction process.

Vygotsky (1978) paid attention to this issue when developing the concept of the Zone of Proximal Development, which meant the distance between the learner's real and potential level of development. The real level of development refers to the things that have already been learnt. The potential level of development refers to the things that are not mastered yet, but which are to be learnt later. To make learning possible, an individual must act at the potential level of development, which is not possible without community-based (e.g. an experienced professional's or a peer's) support. The learner's level of development and learning potential must be recognised and efforts made to help him/her through interpsychological scaffolding to change the potential level into a real level. The learner can be supported e.g. by interactive methods or demonstrations. When learning increases, it is important that the learner is able to monitor and direct his/her learning process by reflecting on the learning events.

\section{Learning as participation}

In sociocultural learning (Wenger, 1998, 2009; also Schirato \& Yell, 2000, pp. 10910 ), attention is paid especially to participation in a community in which members proceed by working actively towards a goal. The members require both commitment and reciprocal responsibility, which connects the members of the community to each other and motivates working. An individual's own understanding is constructed through acting in the community and perceiving its role. Expertise will develop in interaction when the members share their knowledge and support each other to develop their competences connected to the activities in the given context.

Sfard (1998) describes the issue through knowledge acquisition and participation metaphors, which have often been quoted. The knowledge acquisition metaphor refers to individual constructive learning in which the learners save the knowledge transferred 
to them by teaching, mainly in linguistic form, or the knowledge that they have read from books. Knowledge is saved into the 'containers' of their memory, without participating in any action that would require the application of that knowledge. The participation metaphor presents learning as participation in a community's action. Knowledge is created in the social practices of a community and utilised in analysing new things, developing solutions and assessing the outcomes. Learning makes a circle, which, at its best, will lead to cyclically proceeding broad progress.

Participating in a community's action also means socialising in the community, where, through action, a member gradually adopts the language, habits and methods of the community and moves from the margins towards plenipotentiary membership (Lave \& Wenger, 1991). Wenger (1998, p. 153; 2009, p. 210) specifies that participation not only shapes an individual's action, but also his (or her) identity - how he views himself, his belonging to the community and his action in it. Understandable, practicable and familiar things increase belonging, while their opposites increase 'not-belonging'.

In the identity-construction process based on participation, the community provides the framework for developing competence. Consequently, the individual begins to perceive targets for developing his competence, which earlier seemed unreachable but now appear as possibilities. The process proceeds through several milestones along with the action in the community (Hakkarainen et al., 2004, p. 221). Some scholars (e.g. Jarvis, 2009, p. 25; Wenger, 2009, p. 210-11) have stated that the meanings of action become organised in both individual and collective reflection during which the events are dealt with from many angles. Identity becomes constructed when an individual interprets his doings and gives them meanings. The incidents, as realistic events, are examined, also including any negative incidents and feelings.

According to Mezirow (2009), reflection has an essential role as a part of meaningful problem-oriented learning. The starting points of action, process and contents (e.g. the solutions that are developed and the conceptions that have arisen) are evaluated critically, which contributes to the construction of shared understanding in the community, learning from others, and questioning everyday beliefs and the issues that are taken for granted. Over the course of time, this organised understanding will be utilised when one is faced with new situations. Gradually, the kind of learning will be acquired that is apparent in active routines and automatised performances of skills. From the viewpoint of identity development, an individual's understanding of community action and his membership in it becomes clearer (Hakkarainen et al., 2004).

Learning as participation has been examined in music education e.g. by Partti and Karlsen (2010; also Salavuo, 2006), who clarified the action processes of open online music communities. The development of the internet and the better availability of low-cost equipment have brought music learning and making it accessible to nearly everybody. A research report explains how the 'Mixer' community members made music, commented actively on each other's music pieces and supported each other in the creative processes. The implication for music education is consistent with Wenger's (1998) research. As an implication for music education, Partti and Karlsen (2010, p. 379) state, 'the important contribution of autonomous learning practices and peer-directed learning to formal music education are current insights that must be weighed'. Through this form of action, participation in musical communities can be added to music education. 


\section{Sociocultural learning in popular and jazz music}

Popular and jazz music have traditionally been learnt in interaction with experienced and peer musicians, for instance by discussing, listening, observing and imitating. The tradition is seen in the jazz jam sessions, which have been important occasions for young developing musicians to become influenced and taught by more experienced musicians (Knowles, 1997, pp. 211-12; also Gridley, 2003; Green, 2008). In the studies on learning jazz music, researchers have noticed the emphasis on contexts, wide social interaction, belonging to social networks and learning by ear (Berliner, 1994; Laughlin, 2001; Louth, 2006; Watson, 2008). The challenge for formal music education has been one of how to pay attention, in practice, to the issues mentioned above.

According to Gatien (2009, p. 95), jazz music education has 'focused more on "what" has been transmitted than "how" that transmission has occurred', which has meant that 'the traditional ways of transmitting this music have been changed, compromised, or subverted to formal methods of instruction that fit more comfortably in the formal habitat, or are more efficient in the context of classroom or group settings'. In educational implementations, the typical way that pop and jazz music mediate musical tradition should be taken into account in a more comprehensive way than they are today (Gatien, 2009, p. 114). Thus, from the viewpoint of formal education, a central issue is how and in which situations is jazz music learnt.

In learning, authentic experiences and an understanding of their meanings are significant for the learner. Bereiter and Scardamalia (1993) recommend such learning environments and ways of acting in which expertise and skills will be used. The challenge, however, is that a music student, for instance, in a conservatory, does not necessarily have the possibility of interacting musically with experienced pop and jazz music professionals.

\section{Data and analysis: communities of practice in the conservatory}

Conservatories in Finland belong to publicly funded educational organisations which offer studies for the secondary vocational qualification in music (120 study weeks). This research examines how action in communities of practice is connected to the music students' learning in a conservatory. The study consists of 11 popular and jazz music workshops as part of the vocational education in the Conservatory of Oulu, Finland from 2003-2011 with 62 students aged 17-24 years as participants. The basis of the workshop implementations was having a professional musician to work, exercise and perform with the students according to popular and jazz music traditions.

A workshop (Fig. 1) was started with a co-planning and goal-setting discussion between the students, the teacher and a professional musician. In the planning session, the participants discussed the musical theme and challenges with respect to the students' skills. After deciding on the theme, the follow-up tasks and preparation duties were agreed on. The students wrote down their personal workshop learning goals on structured forms.

The next period involved practising the music included in the workshop material. The students worked on the music independently, and under the supervision of their 


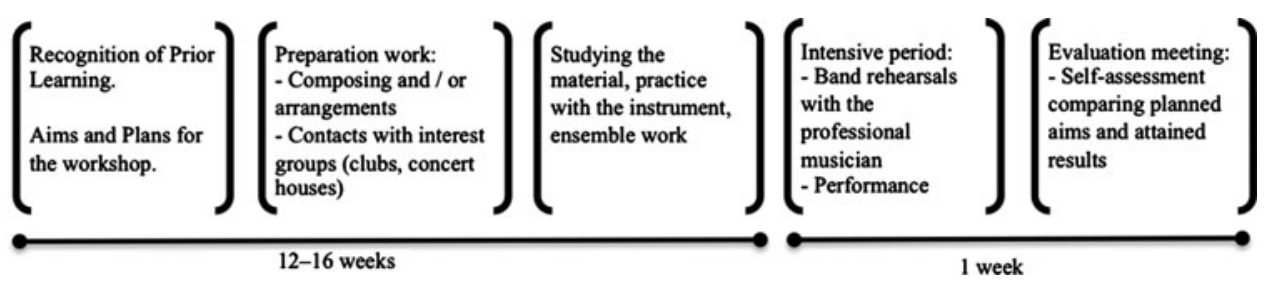

Fig. 1 The steps of progress in the workshop (see Virkkula, 2015).

instrumental teachers and as an ensemble guided by the workshop teacher in charge. A one week intensive period was carried out so that the professional musician arrived on the Monday and started playing with the students. These days typically lasted for 6-7 hours. At the end of the week, a performance was arranged, which was followed by a joint-evaluation discussion. Individual workshop feedback was provided in relation to the set goals.

The present research is a qualitative case study whose aim is to increase understanding about the cooperation of music students and professional musicians in workshops. The research describes and evaluates the connections of a limited case - the workshop method - to student learning in the framework of sociocultural learning (Stake, 1995; Yin, 2009 , p. 3). It is typical of case studies to observe the cases in their contexts by referring to individuals, e.g. student or employee cases, lawsuits, or more general cases, such as training methods and various evaluations concerning development projects (Eriksson \& Kovalainen, 2008). Consequently, a case study need not necessarily be limited to only one case (Yin, 2009, p. 20).

In principle, the present research could also be regarded as action research. This is not, however, the case, since the researcher did not participate in the workshops and the research process did not include interventions typical of action research (Atweh et al., 1998).

The research material was collected in two phases. At the beginning of workshop work (phase 1), students $(\mathrm{N}=62)$ wrote their structured workshop plans in which they outlined their learning goals. Writing the plan proceeded under the guidance of the following questions: 'How did you participate in preparing the workshop?', 'Describe the theme of the workshop, for instance its music genre', 'How do you intend to prepare for the workshop?', 'What would you like to learn in workshop work?' and 'What other expectations do you have concerning workshop work, the professional musician, the workshop concert?'

After the workshop (phase 2), the students $(\mathrm{N}=62)$ reflected on their experiences of the workshop guided by the following open questions: 'Describe your collaboration with the professional musician', 'What did you learn in the workshop?' and 'What could you have done in another way?'

The researcher analysed the material produced by the students using content analysis (Berg \& Lune, 2012; Schreier, 2012, pp. 2-5; also Krippendorff, 2004), which is a widely used method in the systematic analyses of diverse materials in qualitative research. In the studies utilising content analysis, the material is arranged so that the matters of interest in the study can be constructed into a clear interpretation and description. The actual 
analysis is done e.g. of a text, which can be written by research persons or transcribed from interviews.

A content-analysis process is usually started by examining the texts and reducing the expressions. This is followed by looking for similarities and differences in the text, after which the material is tabulated, for instance, according to theoretical or conceptual systems. In such cases, the basis of the analysis is some aspect which is justified from the viewpoint of the research that provides the framework for the examination of the material (Miles \& Huberman, 1994; Schreier, 2012). The method also allows an analysis to be built on a theory or conceptual organisation which makes it possible to collect the kind of data that refer to the theory in question (Marshall \& Rossman, 2011).

The research material was transcribed, after which the textual expressions were tabulated into the categories describing communities of practice in the following way: (1) joint enterprise in action, (2) mutual engagement to reach the goal and (3) shared sociocultural repertoire connecting the members of the community (Wenger, 1998, pp. $72-$ 85). The tabulation made it possible to examine the material widely from the viewpoints of the students, workshops and categories and also to collect quantitative data for these aspects. Through this kind of combination of research methods, using a 'mixed-methods' style, it is possible to finalise the research results for qualitative case studies (Creswell \& Plano Clark, 2011, pp. 4-5; also Patton, 2002).

\section{Results and discussion}

Firstly, the research revealed that workshop work in a conservatory was similar to the action in Wenger's communities of practice (1st research question). The workshop members were united by the goal of making music and of implementing a successful performance. A clear goal linked the students together and motivated them to work for a shared aim (see Wenger, 1998, p. 73; cf. Folkestad, 2006). This kind of goal setting for the students' work in the workshops was connected to their development as musicians.

I try to reach the genre in my playing, develop my playing on the basis of original pieces. ... I try to control my nerves. (A21)

I want to get the best possible conception of the usage of my instrument in the genre in question. (A30)

(I want to learn) observation of and listening to the band. New ways to realise musical issues. I hope I would develop in all parts of playing. . . I I hope for a cosy atmosphere and good supervision as well as a kind of high standard of requirements so that I can get the best possible out of me. (A45)

Of course, I want to learn new pieces, but also ideas of how to realise them with the band. I also want to measure my skills and see if I am able to work with a professional musician. ... I hope that I will get a lot of new ideas of my own during the workshop. (A35)

The performance connected to the workshop had a significant role with respect to reaching the goals. The students experienced it as an important part of workshop work for two reasons: it motivated them to practise their parts carefully and it inspired them to do their best (see Pintrich \& McKeachie, 2000; O’Neill \& McPherson, 2002). 
The performance was a good final culmination to the workshop and also gives energy to practising. (B22)

In a concert, everyone wants to give his/her best; so s/he has to work to attain it. (A3) The gig is like a prize after well-done work and a chance to show (what you have achieved). (A13)

Learning in communities of practice appears in the members' ability to control a shared sociocultural repertoire, for instance, artistic expression, procedures and appropriate language. The quotations reveal how music students use the concepts of the field in question when they describe their action and learning in the workshops.

A piano is a good instrument in an orchestra to strengthen other parts, as it has a strong attack. Although it is not highly audible, its effect is considerable. (A20)

I learnt jazz phrasing mainly by observing XX (the name of the musician), and the common improvisation mornings of all singers were splendid from the viewpoint of scat singing. (A48)

Four-part singing harmonies require exact listening to both the band and other singers. The role of a background singer cleared up to me nicely. (A32)

I got many hints about auditory images of the stemmas that different instruments have in an orchestra. I will benefit from them when I get acquainted with orchestral arrangements and I will try to make something of my own of them. (A20)

From the viewpoint of the development in musicianship (2nd research question), the workshops influenced both the development of the student's musical skills and the key competences of lifelong learning, which are e.g. self-motivation and activity (cf. European Parliament, 2006). Preparing for a performance appeared to be a process which required the students to take responsibility and initiative. Goal-oriented efforts in practicing with one's instrument and working as an ensemble seemed to lead students towards noticing the significance of committed action in a musician's work.

(The workshop) told me a lot about a musician's everyday life, and the practical experience taught me how fast a performance repertoire can be put together, what pre-preparations must be done. (A60)

When my own parts are well under control before the ensemble practice, everything is easier. The artistry in music may get out. (A55)

Together with the band, we have studied through all the pieces and thought of the arrangements. ... I have trained for my parts both with the band and by myself. (A45)

The students' statements reveal how workshop work was connected to their understanding of the work content of a musician, for instance, how to act in order to get the appropriate results. Collective reflection and writing the feedback on their experiences immediately after the performance organised the students' views of a musician's work.

Participation in the workshop work not only shaped the students' action, but also how they saw themselves and their sense of belonging and action in relation to the community (Wenger, 1998, 2009). Collaboration with a professional musician in a music community supported a growth in identity by providing the framework for developing and using the 
skills. The students experienced how coping with the workshop challenges had positive connections to the development of their identities as musicians, as the following quotations reveal.

In the beginning, I was dubious of my ability to perform the large vocal ranges and also the stylistically different songs. Still I went through the challenges to victory, and it felt really fine. I learnt again to believe in my abilities throughout the workshop and, in fact, that concentration and practice ensured the successful result. (A23)

In the beginning, the project felt insurmountable due to the challenging pieces that happened to fall on me. Then I set very modest goals for myself and I reached them. I learnt new things in song techniques perhaps because it was necessary for me to cope with the pieces somehow. Now afterwards it is easy to smile at all that wailing and teeth clamping. I did it! Stress endurance and mental resilience grew immensely, which will be of great benefit in future trials. (A22)

In workshop work and the development of the students' skills as musicians, collaboration and interaction with an experienced professional were, according to this research, of great significance. Interaction was not only verbal, but during the student participation, the student could solidify observations in his mind about models of thinking and action which were starting points for imitating and developing personal solutions (cf. Rogoff, 2003; also Bennett, 2005).

$X X^{\prime} \mathrm{s}$ (the name of a professional musician) endless interest in music and us students was a case par excellence. It left a very nice feeling. (...) XX's personality carried me away, and I noticed that I had learnt a lot during those five action-packed days (the intensive period). (A18)

(The professional musician) was able (in the workshop) to loosen playing from schematic approaches and made my motivation towards music greater than ever. (A9)

The (workshop's) atmosphere was really relaxed, which helped with working and the adoption of tunes. The pieces were really jamming/improvisation-based, so we used a lot of time to find the right mood and the same wavelength. (A43)

(It was) Interesting to get new perspectives from a person who has worked in the field of the genre in question for years. A professional musician brings extra motivation to the situation and a desire to succeed. ... His/her positive attitude to collaboration was an extra bonus. (A13)

What I was taught was welcome and reliable and encourages me to reflect on the things by myself, too. ... They will surely be put into practice. (B 63)

\section{Conclusions}

The conservatory music student should grow into an innovative and active musician who is able to take responsibility for the planning, implementing and monitoring of his/her own work process and outcomes (e.g. Johansson, 2013, p. 278; also Bennett, 2008). The student will learn these objectives when learning is enhanced pedagogically. The studies of a musician are not only concerned with the content that needs to be learned, but also with the methods and outcomes of learning. 


\section{Initiative and responsibility}

- Planning of the workshop, personal learning objectives

- Learning one's own musical part

- Creating solidarity

- Critical reflection on personal and

collaborative actions
2. Work environment

- Reality of the musician's work: planning, rehearsing, performing

- Musician's actual work duties in actual working situations

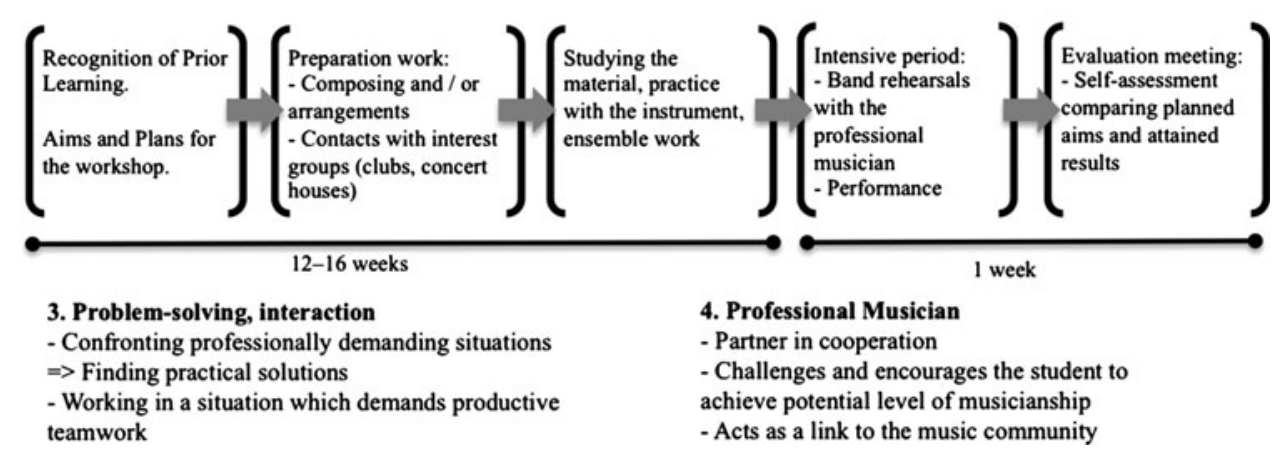

Fig. 2 The learning dimensions of workshop activities (see Virkkula, 2015).

This research shows that collaboration in workshops with professional musicians enabled the very concrete organisation of the students' pictures of professional work and of the knowledge and competences needed in such work (1st research question). Through participation in the work of a music community as a professional's workmate, the students gain access to the expert's tacit knowledge and action culture, and grow into the membership of the community (cf. Wenger, 1998, 2009; Rogoff, 2003; Partti et al., 2013; also Nonaka \& Takeuchi, 1995).

From the viewpoint of training to become a musician (2nd research question), in the workshops, (1) the learner's initiative and readiness to take responsibility are emphasised, (2) action takes place in typical work environments, (3) action is based on problem solutions and interaction, (4) and the role of the visiting professional musician develops from one of a traditional master distributing information and demonstrating the 'right' performance into one of a fellow musician. Figure 2 sums up the learning dimensions of workshop activities and their contents.

The learning dimensions of workshop activities reveal how diversified the musician's work is. The skill of playing is central, but musicianship is a wider concept. Bennett (see 2008, p. 146) presents how musicians have 'multiple roles', which means that 'you can't afford to do conservatory degrees and come out after three years with a degree to play the violin only'.

Collaboration with a professional musician in the workshop does not automatically guarantee attaining the dimensions of student learning. Learning the contents of a musician's work presupposes that the student participates in the workshop proceedings actively. Joint planning of the workshop is of importance, since it helps the students to understand the contents and goals of the activities. What is essential in actual work is the activities which are interactive and authentic in relation to a musician's work, its problems and their solutions. If a student shares in these aspects, he will most obviously increase his 
autonomy and responsibility for his learning, according to this research. This is apparently connected to the increase in study motivation (see Deci \& Ryan, 2000, 2014; Reeve, 2004; Küpers et al., 2014).

The teacher-centred way of acting, which follows the training traditions of music institutions (e.g. Fautley, 2010; Creech, 2012; Partti et al., 2013) makes teachers feel safe, but also brings challenges to student learning. Harré (1983) states that learning in music proceeds through raising interest and involvement to presenting what has been learnt. In the transition period between interest and involvement, the learner can acquire things passively by repeating what the teacher has advised the student to do or he can be guided to make choices actively and take ownership of his learning process (see Hallam, 2001; 2006; Gatien, 2009; O’Neill, 2012; Partti et al., 2013; also Hargreaves, 1986).

From the perspective of learning, it is important to ensure the versatility of teaching and learning environments as well as the student's partnership and autonomy in the learning process (see Brown, 1997; Engle \& Conant, 2002; Ford \& Forman, 2006). The change in the teacher's role from the traditional distributor of information to the educational planner of many-sided supportive environments and the coordinator of learning (cf. Grow, 1991) is a justified area of pedagogical development work in music institutes.

For a music teacher's personal professional development, it would be important to be open to new viewpoints that are justified (see Bennett, 2005, pp. 275-6). Gaining value-added benefit through performance with a professional musician could be realised by participating in a workshop with other music teachers in the conservatory. Some research reports (Virkkula \& Nissilä, 2014; also Olli, 2011; Frisk, 2014) have explained how working with a co-professional - a professional musician - has a positive connection to both the teacher's pedagogical competence and the development of musicianship.

The community of practice has been observed to be meaningful to a person's learning. Does it automatically guarantee good or proper learning? In research concerning the activities and fellowship processes of communities of practice, Lave and Wenger (1991) exemplified the socialisation processes of a new member of the community via the inherent initiation methods. A key objective was to maintain established practices. The characteristics of an active community of practice - shared goals, involvement and common sociocultural tools - are, however, features which also justify the maintenance of traditional approaches and thus limit its development (see Wenger et al., 2002).

Engeström (2001, pp. 136-7; also 1987, 2008) has examined communities of practice from the viewpoint of activity theory. It differs essentially from Wenger's communities of practice in seeing the aim as continually developing expansive activities. The promoters of change evaluate community action, question it and exceed the limits of the job comfort zones of the staff (Engeström, 1987).

Similarly, in the model of innovative information communities developed by Paavola et al. (2004), action is organised through interactive processes towards creating new information and practices supporting it. The skills and knowledge of participants develop in co-operative work through action and reflection. Individual outcomes support the activities of the community, and the practices of the community are used as steps from earlier attainments of individuals towards advancing goals. Knowledge creation is guaranteed by planning, follow-up, guidance and shared 
support among the members. Developing and realising ideas, teamwork skills and organising one's action round the targets of development are emphasised in individual learning.

Based on the above research, communities of practice appear very interesting where arts education is concerned. From the viewpoint of continued research, it would be interesting to explain how strongly the formal music education communities, conservatories among others, are bound up with traditions where pedagogical questions, for instance, are concerned. What kind of outcomes would the communal development of conservatory activities lead to as an expansive process from the viewpoint of competence development in both teachers and students?

\section{References}

AKE, D. (2002) Jazz Cultures. Los Angeles, CA: University of California Press.

ARDICHVILI, A. (2008) Learning and knowledge sharing in virtual communities of practice: motivators, barriers, and enablers. Advances in Developing Human Resources, 10, 541-554.

ATWEH, B., KEMMINS, S. \& WEEKS, P. (1998) Action Research in Practice. Partnerships for Social Justice in Education. London: Routledge.

BALLANTYNE, J. \& LEBLER, D. (2013) Learning instruments informally: A collaborative project across disciplines in popular music and education. In H. Gaunt \& H. Westerlund (Eds), Collaborative Learning in Higher Music Education (pp. 213-218). Farnham: Ashgate.

BENNETT, M. (2005) Musical communication and children's communities of musical practice. In D. Miell, R. MacDonald \& D. J. Hargreaves (Eds), Musical Communication (pp. 261-280). New York, NY: Oxford University Press.

BENNETT, D. (2008) Understanding the Classical Music Profession. The Past, the Present and Strategies for the Future. Farnham: Ashgate.

BEREITER, C. \& SCARDAMALIA, M. (1993) Surpassing Ourselves. An Inquiry into the Nature and Implications of Expertise. Chicago, IL: Open Court.

BERG, B. L. \& LUNE, H. (2012). Qualitative Research Methods for the Social Sciences (8th edn). Upper Saddle River, NJ: Pearson.

BERLINER, P. (1994) Thinking in Jazz: The Infinite Art of Improvisation. Chicago, IL: University of Chicago Press.

BOUD, D. \& MIDDLETON, H. (2003) Learning from others at work: communities of practice and informal learning. Journal of Workplace Learning, 15, 194-202.

BOUD, D., COHEN, R. \& SAMPSON, J. (1999) Peer learning and assessment. Assessment and Evaluation in Higher Education, 24, 413-426.

BROWN, A. N. (1997) Transforming schools into communities of thinking and learning about serious matters. American Psychologist, 52, 399-413.

CARRUCCI, C. (2012) An investigation of social support in adult recreational music ensembles. International Journal of Community Music, 5, 237-252.

COPE, P. (2005) Adult learning in traditional music. British Journal of Music Education, 22, 125-140.

CREECH, A. (2012) The interpersonal behavior in one-to-one instrumental lessons: an observational analysis. British Journal of Music Education, 29, 387-407.

CRESSWELL, J. W. \& PLANO CLARK, V. L. (2011) Designing and Conducting Mixed Methods Research (2nd edn). London: Sage.

DECI, E. \& RYAN, R. (2000) The 'what' and 'why' of goal pursuits: human needs and the self-determination of behavior. Psychological Inquiry, 11, 227-268. 
DECI, E. \& RYAN, R. (2014) The importance of universal psychological needs for understanding motivation in the workplace. In M. Gagné (Ed.), The Oxford Handbook of Work Engagement, Motivation, and Self-Determination Theory (pp. 13-32). Oxford: Oxford University Press.

ENGESTRÖM, Y. (1987) Learning by Expanding: An Activity-Theoretical Approach to Developmental Research. Helsinki: Orienta-Konsultit.

ENGESTRÖM, Y. (2001) Expansive learning at work: toward an activity theoretical reconceptualization. Journal of Education and Work, 1, 133-156.

ENGESTRÖM, Y. (2008) From Teams to Knots: Activity-Theoretical Studies of Collaboration and Learning at Work. New York, NY: Cambridge University Press.

ENGLE, R. A. \& CONANT, F. R. (2002) Guiding principles for fostering productive disciplinary engagement: explaining an emergent argument in a community of learners classroom. Cognition and Instruction, 20, 339-483.

ERIKSSON, P. \& KOVALAINEN, A. (2008) Qualitative Methods in Business Research. London: Sage.

EUROPEAN PARLIAMENT (2006) Recommendation of the European Parliament and of the Council of 18 Dec 2006 on Key Competences for Lifelong Learning (2006/962/EC). http://eur-lex.europa.eu/LexUriServ/LexUriServ.do?uri=CELEX:32006H0962:EN:NOT.

FAUTLEY, M. (2010) Assessment in Music Education. Oxford: Oxford University Press.

FEICHAS, H. (2010) Bridging the gap: informal learning practices as a pedagogy of integration. British Journal of Music Education, 27, 47-58.

FINNEGAN, R. (1989) The Hidden Musicians: Music Making in an English Town. Cambridge: Cambridge University Press.

FINNEY, J. \& PHILPOTT, C. (2010) Informal learning and meta-pedagogy in initial teacher education in England. British Journal of Music Education, 27, 7-19.

FOLKESTAD, G. (2006) Formal and informal learning situations or practices vs formal and informal ways of learning. British Journal of Music Education, 23, 135-145.

FORD, M. J. \& FORMAN, E. A. (2006) Redefining disciplinary learning in classroom contexts. Review of Research in Education, 30, 1-32.

FRISK, T. (2014) Guide for the Implementation of Vocational Teachers' Work Placement Periods. Helsinki: The Finnish National Board of Education.

GATIEN, G. (2009) Categories and music transmission. Action, Criticism, and Theory for Music Education, 8, 94-119.

GAUNT, H. \& WESTERLUND, H. (2013) Prelude: the case for collaborative learning in higher music education. In H. Gaunt \& H. Westerlund (Eds), Collaborative Learning in Higher Music Education (pp. 1-12). Farnham: Ashgate.

GREEN, L. (2001) How Popular Musicians Learn: A Way Ahead for Music Education. London: Ashgate.

GREEN, L. (2006) Popular music education in and for itself, and for 'other' music: current research in the classroom. International Journal of Music Education, 24, 101-118.

GREEN, L. (2008) Music, Informal Learning and the School: A New Classroom Pedagogy. Aldershot: Ashgate. GRIDLEY, M. (2003) Jazz Styles: History and Analysis (8th edn). Upper Saddle River, NJ: Prentice Hall.

GROW, G. O. (1991) Teaching learners to be self-directed. Adult Education Quarterly, 41, 125-149.

HAKKARAINEN, K., LONKA, K. \& LIPPONEN, L. (2004) Tutkiva oppiminen [Exploratory learning]. Helsinki: WSOY.

HALLAM, S. (2001) The development of expertise in young musicians: strategy use, knowledge acquisition and individual diversity. Music Education Research, 3, 7-23.

HALLAM, S. (2006) Music Psychology in Education. London: University of London.

HARGREAVES, D. (1986) The Developmental Psychology of Music. Cambridge: Cambridge University Press.

HARRÉ, R. (1983) Personal Being. A Theory for Individual Psychology. Oxford: Basil Blackwell. 
JAFFURS, S. E. (2004) The impact of informal music learning practices in the classroom, or how I learned how to teach from a garage band. International Journal of Music Education, 22, 189-200.

JARVIS, P. (2009) Learning to be a person in society: learning to be me. In K. Illeris (Ed.), Contemporary Theories of Learning (pp. 21-34). London: Routledge.

JOHANSSON, K. (2013) Undergraduate student's ownership of musical learning: obstacles and options in one-to-one teaching. British Journal of Music Education, 30, 277-295.

KIETZMANN, J., PLANGGER, K., EATON, B., HEILGENBERG, K., PITT, L. \& BERTHON, P. (2013) Mobility at work: a typology of mobile communities of practice and contextual ambidexterity. Journal of Strategic Information Systems, 22, 282-297.

KENNY, A. (2014) Practice through partnership: examining the theoretical framework and development of a 'community of musical practice'. International Journal of Music Education, 32, 396-408.

KNOWLES, S. (1997) The Birth of Bebop: A Social and Musical History. Los Angeles, CA: University of California Press.

KRIPPENDORFF, K. (2004) Content Analysis: An Introduction to its Methodology. London: Sage.

KÜPERS, E., VAN DIJK, M., McPHERSON, G. \& VAN GEERT, P. (2014) A dynamic mode that links skill acquisition with self-determination in instrumental music lessons. Musicae Scientiae, 18, 117-134.

LATUKEFU, L. \& VERENIKINA, I. (2013) Expanding the master-apprentice mode: tool for orchestrating collaboration as a path to self-directed learning for singing students. In H. Gaunt \& H. Westerlund (Eds), Collaborative Learning in Higher Music Education (pp. 101-110). Farnham: Ashgate.

LAUGHLIN, J. E. (2001) The use of notated and aural exercises as pedagogical procedures intended to develop harmonic accuracy among beginning jazz improvisers. PhD dissertation, University of North Texas. http://digital.library.unt.edu/ark:/67531/metadc2886/.

LAVE, J. \& WENGER, E. (1991) Situated Learning: Legitimate Peripheral Participation. Cambridge: Cambridge University Press.

LEBLER, D. (2007) 'Student-as-master? Reflections on a learning innovation in popular music pedagogy. International Journal of Music Education, 25, 205-221.

LEPPÄNEN, T., UNKARI-VIRTANEN, L. \& SINTONEN, S. (2013) Kriittinen kulttuurikasvattaja ja musiikkikasvatuksen traditiot [Critical culture educator and music educational traditions]. In M-L. Juntunen, H. M. Nikkanen \& H. Westerlund (Eds), Musiikkikasvattaja kohti reflektiivistä käytäntöä [Music educator towards reflective practice] (pp. 321-346). Jyväskylä: PS-kustannus.

LOUTH, J. P. (2006) Lifelong learning and the informally trained jazz artist. International Journal of Community Music. www.intellectbooks.co.uk/MediaManager/Archive/IJCM/Volume\%20D/08\%20Louth.pdf.

LUFF, P. \& LEBLER, D. (2013) Striking a balance in brass pedagogy: collaborative learning complementing one-to-one tuition in the conservatoire curriculum. In H. Gaunt \& H. Westerlund (Eds), Collaborative Learning in Higher Music Education (pp. 173-178). Farnham: Ashgate.

MANS, M. (2009) Informal learning and values. Action, Criticism, and Theory for Music Education, 8, 80-93.

MARSHALL, C. \& ROSSMAN, G. B. (2011) Designing Qualitative Research. Thousand Oaks, CA: Sage.

MEZIROW, J. (2009) Transformative learning theory. In J. Mezirow \& E. W. Taylor (Eds), Transformative Learning in Practice (pp. 18-32). San Francisco, CA: Jossey Bass.

MILES, M. B. \& HUBERMAN, A. M. (1994) Qualitative Data Analysis, 2. Thousand Oaks, CA: Sage.

NONAKA, I. \& TAKEUCHI, H. (1995) The Knowledge-Creating Company. How Japanese Companies Create the Dynamics of Innovation? New York, NY: Oxford University Press.

OLLI, T. (2011) Työelämäjaksojen merkitys ammatinopettajien ammatilliselle kasvulle [The role of work placement periods in vocational teachers' professional growth]. Tampere: University of Tampere.

O'NEILL, S.A. (2012) Becoming a music learner: towards a theory of transformative music engagement. In G. E. McPherson \& G. F. Welch (Eds), The Oxford Handbook of Music Education, Vol. 1 (pp. 163-186). Oxford: Oxford University Press. 
O'NEILL, S. A. \& MCPHERSON, G. (2002) Motivation. In R. Parncutt \& G. McPherson (Eds), The Science and Psychology of Music Performance (pp. 31-46). Oxford: Oxford University Press.

PAAVOLA, S., LIPPONEN, L. \& HAKKARAINEN, K. (2004) Models of innovative knowledge communities and three metaphors of learning. Review of Educational Research, 74, 557-576.

PARTTI, H. \& KARLSEN, S. (2010) Reconceptualising musical learning: new media, identity and community in music education. Music Education Research, 12, 362-382.

PARTTI, H. \& WESTERLUND, H. (2013) Envisioning collaborative composing in music education: learning and negotiation of meaning in operabyyou.com. British Journal of Music Education, 30, 207-222.

PARTTI, H., WESTERLUND, H. \& BJÖRK, C. (2013) Oppimiskäsitykset reflektiivisen musiikkikasvattajan toiminnan ohjaajina [Views of learning as guidelines for the reflective music educator]. In M-L. Juntunen, H. M. Nikkanen \& H. Westerlund (Eds), Musiikkikasvattaja kohti reflektiivistä käytäntöä [Music educator towards reflective practices] (pp. 54-70). Jyväskylä: PS-kustannus.

PATTON, M. Q. (2002) Qualitative Evaluation and Research Methods. Thousand Oaks, CA: Sage.

PINTRICH, P. R. \& MCKEACHIE, W. J. (2000) A framework for conceptualizing student motivation and selfregulated learning in the college classroom. In P. R. Pintrich \& P. Ruohotie (Eds), Conative Constructs and Self-Regulated Learning (pp. 31-50). Saarijärvi: Saarijärven Offset Oy.

PURMA, R. (2012) Musiikkialan perustutkinnon v. 2005-2010 suorittaneiden sijoittuminen työelämään ja jatko-opintoihin. [How those who had completed their vocational upper secondary qualifications in music during the years 2005-2010 were later positioned in the working life and postgraduate studies]. Helsinki: The Conservatoire Association of Finland.

REEVE, J. (2004) Self-determination theory applied to educational settings. In E. L. Deci \& R. M. Ryan (Eds), Handbook of Self-Determination Research (pp. 183-204). Rochester, NY: University of Rochester Press.

RIKANDI, I. (2013) Liberation through collaboration: a project of piano vapaa säestys group studies in Finnish music teacher education. In H. Gaunt \& H. Westerlund (Eds), Collaborative Learning in Higher Music Education (pp. 187-192). Farnham: Ashgate.

ROBINSON, T. (2012) Popular musicians and instrumental teachers: the influence of informal learning on teaching strategies. British Journal of Music Education, 29, 359-370.

ROGOFF, B. (2003) The Cultural Nature of Human Development. New York, NY: Oxford University Press.

SADLER, D. R. (2005) Interpretations of criteria-based assessment and grading in higher education. Assessment and Evaluation in Higher Education, 30, 175-194.

SALAVUO, M. (2006) Open and informal online communities as forums of collaborative musical activities and learning. British Journal of Music Education, 23, 253-271.

SCHIRATO, T. \& YELL, S. (2000) Communication and Culture Literacy. St Leonards, NSW: Allen \& Unwin.

SCHREIER, M. (2012) Qualitative Content Analysis in Practice. Thousand Oaks, CA: Sage.

SFARD, A. (1998) On two metaphors for learning and the dangers of choosing just one. Educational Researcher, 27, 4-13.

STAKE, R. (1995) The Art of Case Study Research. Thousand Oaks, CA: Sage.

THORPE, V. (2012) Assessment rocks? The assessment of group composing for qualification. Music Education Research, 14, 417-429.

VÄKEVÄ, L. (2010) Garage band or GarageBand ${ }^{\circledR}$ ? Remixing musical futures. British Journal of Music Education, 27, 59-70.

VAN ZELM, G. (2013). From competitors to colleagues: the experience of devising a peer-learning environment in a vocal department. In H. Gaunt \& H. Westerlund (Eds), Collaborative Learning in Higher Music Education (pp. 179-186). Farnham: Ashgate.

VIRKKULA, E. (2015). Informal in formal: the relationship of informal and formal learning in popular \& jazz music master workshops in conservatoire. International Journal of Music Education, In press.

VIRKKULA, E. \& NISSILÄ, S-P. (2014) In-service teachers' learning through integrating theory and practice. SAGE Open Journal, 4, 1-8. 
VYGOTSKY, L. S. (1978) Mind in Society: The Development of Higher Psychological Processes. Cambridge, MA: Harvard University Press.

WALSER, R. (1993) Out of notes: signification, interpretation, and the problem of Miles Davis. Musical Quarterly, 77, 343-365.

WATSON, K. E. (2008) The Effect of Aural Versus Notated Instructional Materials on Achievement and Self-Efficacy in Jazz Improvisation. Ann Arbor: ProQuest Information and Learning Company.

WELLS, G. (1999) Dialogic Inquiry: Towards a Sociocultural Practice and Theory of Education. Cambridge: Cambridge University Press.

WELLS, G. \& CLAXTON, G. (2002) Introduction: sociocultural perspectives on the future of education. In G. Wells \& G. Claxton (Eds), Learning for Life in the 21st Century (pp. 1-17). Oxford: Blackwell.

WENGER, E. (1998) Communities of Practice: Learning, Meaning, and Identity. Cambridge: Cambridge University Press.

WENGER, E. (2009) A social theory of learning. In K. Illeris (Ed.), Contemporary Theories of Learning: Learning Theorists in Their Own Words (pp. 209-218). London: Routledge.

WENGER, E., MCDERMOTT, R. \& SNYDER, W. M. (2002) Cultivating Communities of Practice. Boston, MA: Harvard Business Press.

WRIGHT, R. \& KANELLOPOULOS, P. (2010) Informal music learning, improvisation and teacher education. British Journal of Music Education, 27, 71-87.

YIN, R. K. (2009) Case Study Research: Design and Methods (4th edn). Thousand Oaks, CA: Sage.

Esa Virkkula has been a music teacher and freelance musician since 1991. He has planned and implemented popular and jazz music training programmes at various levels of education. Virkkula's research interests have been cooperation of educational institutions and work life, and different ways of carrying out on-the-job learning. These themes he has dealt with in his teaching, conference proceedings and articles. As a musician Virkkula has performed with a number of respected artists, e.g. Randy Brecker, Bobby Shew, Nils Landgren and Victoria Tolstoy. 